\title{
Horace Barlow. Scientist of vision
}

\author{
Horace Basil Barlow, Fellow of the Royal Society, winner of the Australia Prize, the Royal Medal of the Royal Society \\ and the Schwartz Prize of the Society for Neuroscience, died on 5 July 2020 at the age of 98, 10 days after suffering \\ a stroke. As news spread among his former students and collaborators, one phrase recurred again and again in the \\ messages of nostalgic reflection: 'the end of an era'.
}

$\mathrm{H}$ orace Barlow's familial lineage extends back through a constellation of famous names. He spoke fondly (never boastfully) about his great-grandfather, Charles Darwin, and about Darwin's grandfathers, the remarkable Erasmus Darwin and Josiah Wedgewood. The family tree bore rich fruit, not only in science (including Francis Galton) but also art (Gwen Raverat), poetry (Ruth Padel), classics (F. M. Cornford) and music (Ralph Vaughan-Williams); plus a host of eminent doctors and politicians. Horace's father, Sir Alan Barlow, was a senior civil servant and an expert on Chinese ceramics.

You might think that Horace would have attributed his early love of science to his illustrious male forebears, but he gave most credit to his mother, Nora Darwin. Although she had no formal university education, she studied botany and genetics at Cambridge and published important papers on plant genetics with William Bateson.

Winchester College, where Horace was a schoolboy, was strong in mathematics. His contemporaries Freeman Dyson, James Lighthill and Christopher Longuet-Higgins became leading theoreticians or applied mathematicians. Horace was restricted to the '4-hour mathematics' stream (because he had decided to study medicine), but mathematical rigor always underpinned his science.

From 1940-44, Horace studied Natural Sciences at Trinity College Cambridge. His Director of Studies was the eminent biophysicist and later visual physiologist, William Rushton, with whom he had a lifelong friendship and scientific interaction, built on both affection and rivalry. In his third undergraduate year, Barlow published his first paper, in Nature, with Rushton, on single-fiber action potentials recorded from the median giant axon of the intact earthworm. He won a Rockefeller studentship for clinical training at Harvard, but delayed his departure, doing a year of 'war-effort' research on the design of self-contained oxygen systems for scuba diving at the Medical Research Council (MRC) laboratories in Hampstead, London.

At Harvard (1944-46), Horace published papers on stimulation of the eye by magnetic
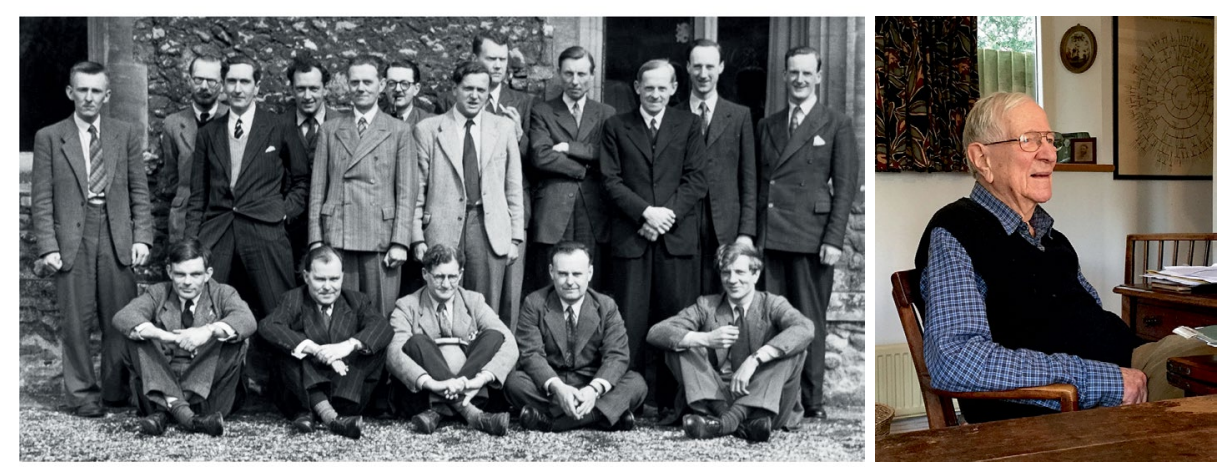

Credit: Left: the Ratio Club in Cambridge, May 1952. Back row: Harold Shipton, John Bates, William Hick, John Pringle, Donald Sholl, John Westcott, Donald Mackay. Middle row: Giles Brindley, Turner McLardy, Ross Ashby, Tommy Gold, Albert Uttley. Front row: Alan Turing, Gurney Sutton, William Rushton, George Dawson, Horace Barlow. (Photo: Wellcome Collection, archive reference GC/179/B.25, used under CC BY / Cropped). Right: Horace Barlow at home in Cambridge, March 2016 (Photo: Ida Barlow).

and electric fields, which initiated a long-standing interest in the mechanisms of adaptation to light and darkness. On his return to England, he quickly completed his medical degree, but both his heart and his head were steering him toward academic research. He won an MRC research studentship and worked for 3 years (1947-50) in Cambridge under Edgar Adrian, who had won the Nobel Prize (with Charles Sherrington) in 1932 for his observations on the activity of sensory nerves. After fruitless efforts to arrange a meeting with the hyperactive Lord Adrian, Horace managed to trap him by standing in front of his bicycle. In their brief conversation, Adrian suggested that he should follow up W. H. Marshall's and S. A. Talbot's hypothesis that tiny eye movements during fixation improve visual acuity. Horace devised a highly sensitive method of measuring eye movements by photographing a reflection from a droplet of mercury placed on the edge of the cornea of a volunteer, lying supine on a stone slab, with an iron frame and wedges to hold the head still. With this torturous device Horace established that small oscillatory eye movements are not needed for good vision.

From 1950, Horace remained in Cambridge on a variety of appointments for more than a decade, except for a period with Steve Kuffler in Baltimore, Maryland, in 1953 and with Dick Hill in Berkeley, California, in 1963. He moved to Berkeley in 1964 and, together with Bill Levick and Gerald Westheimer, he created a mecca for vision research. In 1973 he returned to Cambridge as a Royal Society Research Professor and Fellow of Trinity College, a title he held until his death.

As an undergraduate, Horace had attended the seminars of Frederic Bartlett, Professor of Psychology and a pioneer in the study of human memory. Horace once told me that he couldn't remember much of what Bartlett taught, but he did recall him saying that we tend to remember the first and the last of a series of things that we see or hear. Horace said that he wasn't sure whether it was the first or the last thing that Bartlett said! Horace's curiosity about the fundamental questions of psychology pervaded his work. So too did his interest in the discovery of ethologists, Konrad Lorenz and Niko Tinbergen, that adaptive and apparently intelligent animal behavior can be triggered automatically by simple, distinctive features in the visual scene.

In 1949 Horace began work on the properties of ganglion cells in the frog's retina, which was the start of a lifelong 
effort to link neural activity with behavior, perception and understanding. Horace made a string of highly original and influential empirical discoveries. $\mathrm{He}$ described lateral inhibition and feature detection in the vertebrate eye (1950); then, with others, changes in receptive field organization during dark adaptation (1957), direction-selectivity in the mammalian retina (1963), perceptual degradation of stabilized retinal images (1963), the role of photoreceptor mechanisms in dark adaptation (1964), disparity selectivity in neurons of the visual cortex (1967) and responses of ganglion cells to single photons of light (1971).

I suspect that Horace would like to think that his most enduring contribution was to argue for a theoretical framework to understanding how the brain works. Even as a research student with Adrian, Horace nurtured an interest in the embryonic field of computing, stimulated, in part, by Norbert Wiener's seminal 1948 book Cybernetics. In 1949 Horace became a founding member of an extraordinary debating society, the Ratio Club (etymology: ratiocination), for people 'who had Wiener's ideas before Wiener's book appeared'. Other members included Tommy Gold (astrophysics), Grey Walter (robotics), Ross Ashby (self-organization), Donald Mackay (machine intelligence), Albert Uttley (conditional probability computing) and Alan Turing (father of AI). Horace was the youngest member.

In parallel with his experimental work, Horace produced a string of highly original theoretical and interpretative papers. By the late 1950s, he was arguing that Shannon's concept of information might be more valuable than conventional statistical approaches in understanding neural coding and efficiency. In the retina, transient responses at light-on and -off, lateral inhibition and feature detection could serve the purpose of reduction of redundancy and signal compression. In a classic paper, 'Single units and sensation: a neuron doctrine for perceptual psychology' (Barlow, H. B. Perception 1, 371-394; 1972), published nearly 50 years ago but still highly influential, Barlow argued that stimulus selectivity, whether genetically determined or individually acquired through plasticity, can minimize the numbers of neurons and impulses involved in representing any scene. He proposed a form of sparse coding in which each visual scene is represented by a small number among an enormous population of 'cardinal cells', each of which corresponds to a meaningful pattern of external events (i.e., with high information content), "of the order of complexity of the events symbolized by a word." At that stage he was skeptical about 'grandmother cells', encoding the pure concept of particular things in the world (the Kantian Ding an sich), although he came close to accepting this late in his life.

Horace was able to make difficult ideas seem simple, in the way that a good conjurer can make the impossible look real. And he had an uncanny capacity for good guesswork. I remember well my first meeting with him, when I arrived in Berkeley in 1965 as his second PhD student. I wanted to follow up Hubel and Wiesel's finding that neurons in the cat primary visual cortex are binocularly driven by investigating how they react to different images in the two eyes. Horace immediately suggested that binocular neurons might play a part in stereoscopic vision, because the similarity of stimulus preference in the two eyes could enable them to respond selectively to retinal disparity. Like any successful gambler, Horace knew how to base expectation on evidence and experience. In 1994 he pointed out that even individual neurons can gather information, make decisions and communicate those decisions reliably_all the conditions for good guesswork. He also pointed out that, given the adaptive value of successful 'guessing', these characteristics are likely to have been selected for during evolution.

Given the sweep of his interestsmedicine, psychology, ethology, cybernetics, neurophysiology-it is no surprise that Horace welcomed the birth of neuroscience and its interdisciplinary goals. He wrote with clarity and originality on topics as challenging as intelligence, language, consciousness and cultural evolution.

Horace Barlow leaves four children from his first marriage, to Ruthala Salaman, three children from his marriage to Miranda Weston-Smith, 13 grand-children and thousands of admirers. The loss of Horace is not the end of an era. The era in neuroscience that Horace strove to establish, like the memory of Horace, is here to stay.

\author{
Colin Blakemore ${ }^{凶}$ \\ Department of Neuroscience and Hong Kong Institute \\ for Advanced Study, City University of Hong Kong, \\ Hong Kong, China.

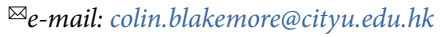

Published online: 7 September 2020

https://doi.org/10.1038/s41593-020-00708-1 